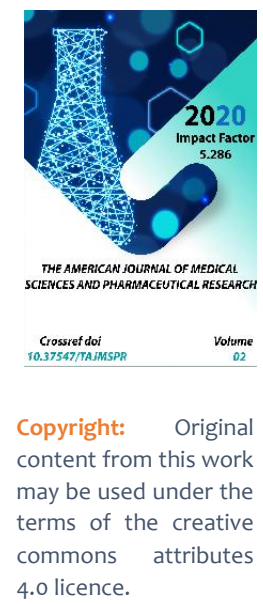

\section{Meaning Of Respiratory Mycoplasma Infection In Children With Bronchial Asthma}

\author{
Gulnoza Aloevna Toshmatova \\ Doctor Of Medical Sciences, Associate Professor, Department Of Children`S Diseases №1, \\ Medical Faculty, Tashkent Medical Academy, Uzbekistan \\ Maftuna Shukhrat Qizi Shakarova \\ Master Student Of 3rd Year, Department Of Children`S Diseases №2, Medical Faculty, \\ Tashkent Medical Academy, Uzbekistan \\ Arzi Ruslanovna Emirova \\ Master Student Of 3rd Year, Department Of Children`S Diseases №2, Medical Faculty, \\ Tashkent Medical Academy, Uzbekistan
}

\title{
ABSTRACT
}

Meaning and role of mycoplasma infection for children with bronchial asthma small studied. By us was inspected 39 children with BA in age from 2 to 14 , from them $27(69,2 \%)$ boys and $12(30,8)$ girls. Obtained data from PChR testing is shown: among the children of patients with BA for 33,3\% (13/39) patients found out M. pneumoniae.; for 66,7\% (26/39) patients and for all children of control group $M$. pneumoniae. it is not discovered (table.№1). For children in a range $2-5$, the more than half $(53,8 \%)$ of children-asthmatics was got positive results of PChR; among the investigated children in age 6-14, only at $46,2 \%$ patients had $M$. pneumonia. Except it, among patients with BA, for $69,2 \%$ boys and $31 \%$ girls made the positive result of $\mathrm{PChR}$, and correlation of sexes was made by 2,2:1.

\section{KEYWORDS}

Bronchial asthma, respiratory infection, mycoplasma infection, children, atopic, atopic dermatitis, food allergy, family allergic anamnesis.

\section{INTRODUCTION}

From data of results of analysis of modern literature in the whole world in the last few years, a tendency is marked to the increase of morbidity bronchial asthma (BA) for children from early age and often has a heavy flow, and the met makes her from $5 \%$ to $15 \%$.

The presence of next triad determines of BA for children: chronic inflammation, bronchial 
obstruction and increasing bronchial reactivity $[11,15,23]$. Wheezing (whistling breathing), shortness of breath, constraint in a breast, cough, products of sputum - clinical symptoms are characteristic for bronchial asthma.[11].

Flow BA for children related to the row of anatomical-physiological features: narrowest of road clearance of bronchial tubes, enhanceable vascularization of respiratory tracts, insufficient rigidity of thorax, elasticity of lungs, weak development of smooth musculature of bronchial tubes, hypersecretion of viscid mucus by gobled cages. Predominance of edema of mucous membrane, resulting in a selection mucuses in the road clearance of bronchial tubes above the spasm of smooth muscles, is another personal touch jf BA for children $[15,23]$.

Causes different irritants of BA in children (atypical, viral infections, trigger factors) under their influence at any time can there is narrowing road clearance of bronchial tubes. In addition in pathogenesis of bronchial asthma, influences to difficult mixture of a few wellknown factors, such as genetic, ecological, dietary changes and professions, confessed as factors of predisposition to bronchial asthma $[2,6]$.

In the last time, the scientists are spare large attention on a role different to the infection at $B A$ in children. An infectious process can be provocateur, as a factor for the attack of bronchial spasma, or sharp viral infection often become reason of intensifying of $B A$ in children. Some infectious microorganisms (viruses, bacteria) considerably influences on the immune reaction of child, promotes secondary to infecting of respiratory tracts; increase of bronchial hyperreactivity and to development of bronchial spasm. Sick children with an atopic form of BA genetically predisposition to the persistent flow of some viral and atypical (intracellular) infections. In pathogenesis of BA the role of infection of respiratory tracts is great. And at intensifying they play not unimportant role. Lately role of atypical causative agents at BA for children (Chl. pneumoniae and M. pneumonia) began to be actively studied [5].

To date it is well-proven that M. pneumonia is one of basic causative agents of pneumonia for children $[1,4,5,6,23]$. This insufficiently known infection can be primary reason of pneumonia for children or because of joining with a secondary infection causes the chronic fever of lungs. Values and role of mycoplasma infection in children with BA small studied, therefore study of role and value of mycoplasma infection in children with BA opens new ideas about the mechanism of development of BA in children.

The aim of our researches is a study of role of respiratory mycoplasma infection in intensifying of BA in children.

\section{MAIN PART}

By us was inspected 39 children with $B A$, in age of from 2 to 14 , from them $27(69,2 \%)$ boys and $12(30,8 \%)$ girls. All children were on a planning inspection and treatment, in periods of 20192020- years on the base of child allergist and pulmonologist departments, at the Multi-field clinic of TMA. Clinical diagnosis of BA was put on the basis of taking the history (life, illness, allergic anamnesis), clinic, results of analyses of laboratory and instrumental research methods. It is diagnosed concordantly on protocol to Ministry health Protection of Republic of Uzbekistan. For determination of fragments of deoxyribonic nucleid acid (DNA) 
of mycoplasma (MP) in sputum at the investigated groups of children, a method was used polymer chain reaction (PChR) in a laboratory to the clinic of Medilux. All inspected children on the basis of laboratory researches we divided into 2 groups. A 1th group was made by 13 (33,3\%) children with the presence of $M$. Pneumoniae a 2 th group was made by $26(66,7 \%)$ children without $M$. Pneumoniae For

\section{RESULTS}

Obtained data from PChR testing is shown: among the children of patients with $\mathrm{BA}$, for $33,3 \%$ (13/39) patients found out $M$. pneumoniae.; for $66,7 \%$ (26/39) patients and for all children of control group $M$. pneumoniae. it is not discovered (table. №1). For children in a range 2-5, the more than half $(53,8 \%)$ of children-asthmatics was got positive results of PChR; among the investigated children in age $6-14$, only at $46,2 \%$ patients had M. pneumonia. Except it, among patients with BA, for $69,2 \%$ boys and $31 \%$ girls made the positive result of $\mathrm{PChR}$, and correlation of sexes was made by $2,2: 1(p=0,648)$.

Table№1. Results of PChR testing

\begin{tabular}{|c|c|c|c|c|c|}
\hline \multirow{2}{*}{$\begin{array}{c}\text { PChR testing on } \\
\text { determination of fragments } \\
\text { of DNA of MP infection }\end{array}$} & \multicolumn{2}{|c|}{$\begin{array}{l}\text { Sick children with BA } \\
\qquad \mathrm{n}(\%)\end{array}$} & \multicolumn{2}{|c|}{$\begin{array}{c}\text { Control group } \\
\mathrm{n}(\%)\end{array}$} & \multirow[t]{2}{*}{ P meaning } \\
\hline & Positive & Negative & Positive & $\begin{array}{c}\text { Negativ } \\
\mathrm{e}\end{array}$ & \\
\hline Results & $13(33.3 \%)$ & $26(66.7 \%)$ & $\mathrm{O}(0 \%)$ & $\begin{array}{c}44(100 \% \\
)\end{array}$ & $<0.001$ \\
\hline Common & \multicolumn{2}{|c|}{$39(100 \%)$} & \multicolumn{2}{|c|}{$44(100 \%)$} & \\
\hline
\end{tabular}

In a table №2 the complaints of sick children are shown with BA both groups. Both them, with MP infection and without a MP infection. For patients 1st groups with the positive PChR testing answer were next complaints: at 46,15\% on a fever $(p=0,135)$, at $76,93 \%$ on a cough $(p=0,023)$, at $84,62 \%$ wheezing sound in a thorax $(p=0,006)$. On survey roentgengraphy of thorax for patients with MP of infection, for $57,7 \%$ patients it is found out single infiltration hearths in lungs. For patients 2nd groups with the negative PChR answer were next 
complaints: at $23,7 \%$ on a fever $(p=0,135)$, at $23,7 \%$ on a cough $(p=0,023)$, at $15,38 \%$ wheezing sound in a thorax $(p=0,006)$. On survey roentgengraphy of thorax for patients with the negative answer of MP of infection, for 32,4\%

TableNo2. Complaints of sick children with BA with positive and negative PChR answers in the presence of M. pneumonia.

\begin{tabular}{|c|c|c|c|c|c|}
\hline \multirow{2}{*}{$\begin{array}{c}\text { Complaints and } \\
\text { symptoms }\end{array}$} & \multicolumn{2}{|c|}{ PChR Positive n (\%) } & \multicolumn{2}{c|}{ PChR Negative n (\%) } & \multirow{2}{*}{ P Meaning } \\
\cline { 2 - 5 } & Positive & Negative & Positive & Negative & \\
\hline Fever & $6(46.15 \%)$ & $7(53.85 \%)$ & $623.07 \%)$ & $20(76.29 \%$ & 0.135 \\
& & & & $3(23.07 \%)$ & 16 \\
$(10(76.93 \%)$ & $10(38.46 \%)$ & $(61.54 \%)$ & 0.023 \\
\hline Cough & $11(84.62 \%)$ & $10(38.46 \%)$ & $2(15.38 \%)$ & 16 & 0.006 \\
\hline
\end{tabular}

At inspection of children with BA, we studied such factors as, seasonal allergy and allergy to the animals (table.№3). From a table №3 evidently, that a seasonal allergy is educed at 17 $(43,6 \%)$ patients, at that time allergy to the animals educed patients at 24 (61,5\%). These factors are to the starting factors, at finding out of anamnesis and diagnostics disease. patients it is found out single infiltration hearths in lungs. 
The American Journal of Medical Sciences and Pharmaceutical Research

(ISSN - 2689-1026)

Published: December 29, 2020 | Pages: 47-54

Table№3. Comparative description between the investigated groups of children with BA and healthy.

\begin{tabular}{|c|c|c|c|c|}
\hline \multicolumn{2}{|c|}{ Variable descriptions } & $\begin{array}{c}\text { Children } \\
\text { with BA n (\%) }\end{array}$ & Healthy n (\%) & P meaning \\
\hline Sex & Boys & $27(69.2 \%)$ & $26(59 \%)$ & 0.233 \\
\hline $\begin{array}{c}\text { Seasonal } \\
\text { allergy }\end{array}$ & Positive & $12(30.8 \%)$ & $18(41 \%)$ & \\
\hline $\begin{array}{c}\text { Allergy to } \\
\text { the } \\
\text { animals }\end{array}$ & Negative & $22(56.4 \%)$ & $19(43.2 \%)$ & \\
& Positive & $24(61.5 \%)$ & $31(70.5 \%)$ & \\
& Negative & $15(38.5 \%)$ & $13(29.5 \%)$ & \\
& & & & \\
\end{tabular}

Table№4. Family atopic anamnesis of the investigated groups of children with BA and healthy

\begin{tabular}{|c|c|c|c|c|c|}
\hline \multirow[t]{2}{*}{ Family anamnesis } & \multicolumn{2}{|c|}{$\begin{array}{c}\text { Children with BA } \\
n(\%)\end{array}$} & \multicolumn{2}{|c|}{$\begin{array}{c}\text { Healthy children } \mathrm{n} \\
(\%)\end{array}$} & \multirow[t]{2}{*}{$\mathrm{P}$ meaning } \\
\hline & Positive & Negative & Positive & Negative & \\
\hline Burdened anamnesis with $\mathrm{BA}$ & $\begin{array}{c}25(64.1 \% \\
)\end{array}$ & $14(35.9 \%)$ & $\begin{array}{c}36(81.8 \\
\%)\end{array}$ & $8(18.2 \%)$ & 0.057 \\
\hline
\end{tabular}




\begin{tabular}{|c|c|c|c|c|c|}
\hline $\begin{array}{c}\text { Burdened anamnesis with } \\
\text { atopic dermatitis }\end{array}$ & $\begin{array}{c}23(58.9 \% \\
)\end{array}$ & $16(41.1 \%)$ & $\begin{array}{c}38(86.4 \\
\%)\end{array}$ & $6(13.6 \%)$ & 0.005 \\
\hline $\begin{array}{c}\text { Burdened anamnesis with } \\
\text { food allergy }\end{array}$ & $32(82.1 \%)$ & $7(17.9 \%)$ & $\begin{array}{c}43(97.7 \\
\%)\end{array}$ & $1(2.3 \%)$ & 0.019 \\
\hline
\end{tabular}

The presence of atopy for family members and bronchial asthma are closely constrained. For children with BA domestic allergic anamnesis (it was educed for family members: atopic dermatitis, bronchial asthma, alimentary allergy) was burdened ( $p=0,05)$, as compared to control groups of the investigated children.

\section{DISCUSSION}

The got analyses of results showed, that for $35,9 \%$ children with BA family anamnesis is one of key risk factors development of BA. Burdened family anamnesis with atopic dermatitis too (as statistically meaningful $(p=0,005))$, plays a not insignificant role as risk factor for development of BA from child's age. This result was educed at $41,1 \%$ as compared to $13,6 \%$ in a control group. It is necessary to take into account, burdened family anamnesis and atopy, not only saved but also strengthens a flow BA and other atopic disease further.

An alimentary or food allergy is in family anamnesis, development matters by child's bronchial asthma. Research results show 17,9\% of asthmatic patients as compared to $2,3 \%$ in a control group $(p=0,019)$. To talk it about that, children with a food allergy in 7,8 time were more often ill asthma, than themes, childrenasthmatics do not have a food allergy.

A food allergy also appeared the marker of weight of bronchial asthma. Results undertaken laboratory studies are determination of DNA of fragments of
M.pneumoniae shows, statistical connection between bronchial asthma and MP infection ( $p$ o,001).

At $33,3 \%$ of sick patients it was got positive reaction on the M.pneumoniae method of $\mathrm{PChR}$, in a control group this index was made by $0,0 \%$.

Sick children with the positive ПЦР result, as compared to the negative patients of $M$. pneumoniae, did not show to the association ( $p=0,44, p=0,64$ and $p=0,19$ accordingly).

Seasonal allergy $(p=0,02)$ and burdened domestic anamnesis, $(p$

\section{CONCLUSION}

Thus, taking the family history has a very large role, showed the presence of atopy (presence of bronchial asthma, atopic dermatitis and alimentary allergy) closely-coupled interface with bronchial asthma. M. pneumonia is closely related to bronchial asthma. She can be counted, as major risk factors at intensifying of bronchial asthma. Mycoplasma an infection aggravates a clinical flow BA in children, and in one season there were a few episodes of intensifying $B A$ in children. A cough and wheeze in a breast are considered the major sign of $M$. pneumonia, but here in a roentgengraphy, defining not maybe. 


\section{REFERENCES}

1. Atkinson T.P., Balish M.F., Waites KB. Epidemiology, clinical manifestations,pathogenesis and laboratory detection of Mycoplasma pneumoniae infections. - FEMS Microbiol. Rev.- 2008.-№32(6).-C.95673.

2. Cengizlier M.R., Misirlioglu E.D. Evaluation of risk factors in patients diagnosedwith bronchial asthma. Allergollmmunopathol (Madr).-2006.№34(1).-C.4-9.

3. Esposito S., Blasi F., Arosio C., Fioravanti L., Fagetti L., Droghetti R et al.Imporance of acute Mycoplasma pneumoniae and Chlamydia pneumonia infections in children with wheezing. EurRespir J.- 2000.№16(6).C.1142-6.

4. Lee KY. Pediatric respiratory infections by Mycoplasma pneumoniae. Expert. Rev Antilnfect Ther.- 2008.-6(4).C.50921.

5. MacDowell AL, Bacharier LB. Infectious triggers of asthma. Immunol AllergyClin North Am.- 2005.№25(1).C.45-66.

6. Maclennan $C$, Hutchinson $P$, Holdsworth S, Bardin PG, Freezer NJ. Airwayinflammation in asymptomatic children with episodic wheeze. PediatrPulmonol.- $\quad$ 2006.- №41(6).C.577-83.

7. Narita M. Pathogenesis of extrapulmonary manifestations of Mycoplasmapneumoniae infection with special reference to pneumonia. JInfectChemother.-2010.-№16(3).-

C.162-9.
8. Agapova. O. Bronchial asthma: receptor interactions and not only ... On the search for new approaches in tactics and treatment and ongoing research. // Honey. gas. - 2017. - No. 74. - S. 12-13.

9. Bazhenov EE, Akhmedov VA, Ostapenko VA Clinical and pharmacological foundations of modern pulmonology: a textbook for the system of postgraduate professional education of doctors. I Moscow: BINOM. Knowledge laboratory, 2015.-55 p.

10. Belevsky AS Global strategy for the treatment and prevention of bronchial asthma (revision 2014) - Moscow: Russian Respiratory Society, 2015. - 148 p.

11. Geppe N.A. The urgency of the problem of bronchial asthma in children // Pediatrics. - 2012. - T. 91, No. 3. -S. 76-82.

12. Zakharova I.A., Belevsky A.S. Possibilities of treating virus-induced bronchial asthma // Bronchial asthma. 2017. - No. 3. From 3-5.

13. Ilyenkova NA Concentrations of cytokines in bronchial asthma in patients depending on the degree of disease control // Doctor.RU. - 2018. No. 4. - P. 44-47.

14. Kostinova M.P., Chuchalina A.G., Guide to clinical immunology in respiratory medicine / Moscow: ATMO, 2016. - 128 p.

15. Kostromina V.P., Strizh V.O., Matvianko Yu.O., Rechkina OO, Yaroshchuk L.B., Doroshenkova A.S. Clinical-andnological criteria for differential diagnosis of bronchial asthma and bronchitis with broncho-obstructive 
syndrome in children // Asthma and allergy. - 2012. - No. 3. - S. 24-27.

16. Kupaev V.I. Cough variant of bronchial asthma // Asthma and Allergy. - 2018. No. 3. From 13-15.

17. Kurbacheva OM, Pavlova KS Phenotypes and endotypes of bronchial asthma: from pathogenesis and clinical picture to the choice of therapy // Russian Allergological Journal. - 2013. - No. 1. - S. 15-24.

18. Lebedenko A. A. Analysis of the association of polymorphic variants of growth factors genes with the risk of developing bronchial asthma in children // Pulmonology. -2018- Vol.-28. No. 1. S. 7-12.

19. Marshalko O.V., Karpovich A.I. Therapy in 3 parts., Study guide / Minsk: RIPO, 2016 - Part 1: Pulmonology. - 2016 .- 202

p.

20. Smolnikova M.V., Smirnova S.V., llyenkova N.A., Konopleva O.S. Immunological markers of uncontrolled course of bronchial asthma in children // Medical Immunology. - 2017. Vol.19, No. 4. S. 453-460.

21. Starostina L.S. Acute respiratory viral infection in children with bronchial asthma // Otorhinolorhinogology and Pulmonology. - 2017.- No. 3. 59-64.

22. Chernussky V.G., Odinets Yu.V., Morozova A.D. The influence of the alpha-blocker pyrroxan on the parameters of bronchial patency in children with bronchial asthma // Medicine of the Year and Tomorrow. 2010. - No. 1. -S. 118-120.

23. Chernysheva OE, MODERN PREDICTIONS ON THE PATHOGENESIS
OF AD IN CHILDREN "Child's Health", 2014 - ISSN 2224-0551 ${ }^{1} 5$ (56) • 2014. 